РОЗУМІННЯ ПСИХІЧНОГО РОЗВИТКУ ЛЮДИНИ: ІСТОРІЯ ПОГЛЯДІВ

\title{
UNDERSTANDING OF MENTAL DEVELOPMENT OF HUMAN BEINGS: HISTORY OF VIEWS
}

УДК 159.9 (01)

DOI https://doi.org/10.32843/26635208.2020.15.11

\section{Мельник О.А.}

к.психол.н., старший науковий співробітник,

докторант факультету психології Київський національний університет імені Тараса Шевченка

\author{
Стаття присвячена висвітленню наукових \\ ідей щодо розвитку психіки людини, адже \\ зазначена проблематика являє собою най- \\ важливіший базис для психологічної науки. \\ Результати дослідження були отримані зав- \\ дяки використанню методу реконструкціі \\ та порівняльно-історичного методу. Пред- \\ ставлені наукові ідеї послідовників київської \\ школи фрілософрської психології. З'ясовано, що \\ наслідуваними ідеями щодо розвитку психіки \\ людини, які були перейняті наступниками \\ у представників київської школи фрілософр- \\ ської психології, виявились такі ідеї: розу- \\ міння розвитку людської психіки як процесу, \\ за якого кількісні ускладнення та змінення \\ переходять у якісні, суттєві та приводять \\ до появи новоутворень (С.Л. Рубінштейн); \\ психічний розвиток як єдність протилеж- \\ ностей, тобто роздвоєння єдиного на \\ взаємовиключаючі протилежності та спів- \\ відношення між ними з наявним впливом \\ зовнішніх і внутрішніх умов, а також єдність \\ i боротьба протилежностей (Г.С. Костюк); \\ розвиток як поступові, відносно незворотні \\ зміни організму в часі, тобто у людини від- \\ бувся не лише процес зростання, а також \\ і процес розвитку, який являє собою якісні \\ зміни (Йозефр Шванцара); одиницею аналізу \\ розвитку психіки виступає вчинок, а куль- \\ тура зазначена як ключовий чинник впливу \\ на психічний розвиток людини (В.А. Роме- \\ нець); розвиток психіки людини на почат- \\ ковому етапі уможливлюється завдяки \\ здатності до відображення і виявляється, \\ по-перше, у відборі чуттєвих, біологічно зна- \\ чущих сигналів (рівень організму); по-друге, \\ у раціональному пізнанні в процесі засвоєння \\ (рівень індивіда), та по-третє, у прочесі \\ творення суспільно-історичного досвіду \\ (рівень особистості) (О.М. Ткаченко); роз- \\ виток психіки людини відбувається стаді- \\ ально (А.В. Брушлінський); головною умовою \\ психічного розвитку $є$ виконання дитиною \\ практичних дій (О.B. Запорожець). \\ Ключові слова: психіка, розвиток психіки, \\ кількісні та якісні зміни.
}

The article is devoted to the coverage of scientific ideas on the development of the human psyche, because these issues are the most important basis for psychological science. The results of the study were obtained through the use of reconstruction methods and comparative-historical method. Scientific ideas of followers of the Kyiv school of philosophical psychology are presented. It was found that the inherited ideas on the development of the human psyche, which were adopted by the successors of the Kiev school of philosophical psychology were the following ideas: understanding the development of the human psyche as a process in which quantitative complications and changes become qualitative, significant and lead to tumors (S.L. Rubinstein); mental development as the unity of opposites, i.e. the bifurcation of the one into mutually exclusive opposites and the relationship between them with the existing influence of external and internal conditions, as well as the unity and struggle of opposites (G.S. Kostyk); development, as gradual, relatively irreversible changes in the body over time, i.e. a person has undergone not only the process of growth, but also the process of development, which is a qualitative change (Josef Schwantsara); the unit of analysis of mental development is the act, and culture is mentioned as a key factor influencing the mental development of man (V.A. Romenets); the development of the human psyche at the initial stage is possible due to the ability to reflect and is manifested, first, in the selection of sensory, biologically significant signals (body level); secondly, in rational cognition in the process of assimilation (the level of the individual), and thirdly, in the process of creating socio-historical experience (the level of personality) (O.M. Tkachenko); the development of the human psyche occurs gradually (A.V. Brushlinskiy); the main condition of mental development is the child's performance of practical actions (O.V. Zaporozhets).

Key words: psyche, development of psyche, quantitative and qualitative changes.
Актуальність теми дослідження. Історія проблеми розвитку психіки являє собою найважливіший базис для психологічної науки. Питання про розвиток психіки пов'язувалося 3 основним питанням філософії про взаємини мислення та буття. Усі відповіді на це запитання, що надавалися за різних часів, за різних соціально-економічних умов, можна звести, власне, до двох напрямів - ідеалістичного і матеріалістичного. Ідеалісти вважали, що дух існував до природи, він $€$ основою буття, а матеріалісти визнавали, що природа породила дух, що матерія $€$ основою буття. Обидві теорії відбивались і в теоріях про суть людської психіки. Отже, історія науки про психіку людини - це історія ідеалістичних і матеріалістичних течій за різних історичних часів.

Виклад основного матеріалу. Українські представники філософської психології кінця XIX - поч. XX ст., такі як С.С. Гогоцький, О.М. Гіляров, Г.І. Челпанов, І.О. Сікорський і В.В. Зеньковський, процес психічного розвитку вбачають саме у якісних змінах змісту психічного, а сам розвиток людської психіки визнають необмеженим, але лише з умовою постійного надбання знань і самовдосконалення Це ключове положення вчених не залишилося поза увагою та віднайшло своїх послідовників у XX - поч. XXIст. 
Розвиток психіки С.Л. Рубінштейн визначає як загальний принцип або метод дослідження всіх проблем психології. «Закономірність усіх явищ, і психічних у тому числі, - пише Рубінштейн, - пізнається лише в їх розвитку, у процесі їх руху та змінення, виникнення та відмирання» [6, с. 91]. Розвитком психіки вважається не лише зростання, переконаний учений, але й змінення як процес, за якого кількісні ускладнення та змінення переходять у якісні, суттєві та приводять до появи новоутворень. Для С.Л. Рубінштейна завдання психології під час вивчення психічного розвитку полягає, по-перше, у виявленні наступності, тобто в розвитку вищих форм психіки на основі нижчих, та якісній своєрідності цих вищих форм (наприклад, свідомість людини порівняно з психікою тварин); по-друге, оскільки психічні явища, як і всі явища природи та суспільного життя, мають своє минуле і майбутнє, свою позитивну і негативну сторону, те, що відживає, і водночас те, що розвивається, справжнім змістом психічного розвитку виступає боротьба внутрішніх протиріч, боротьба між старими формами психіки й новими, що народжуються [6].

Принцип розвитку виступає методологічною основою розуміння процесу становлення особистості у Г.С. Костюка і включає онтогенетичний аспект розвитку її психічних властивостей. Природа людської психіки $є$ біосоціальною. Розвиток Г.С. Костюк визначає як єдність протилежностей, тобто роздвоєння єдиного на взаємовиключаючі протилежності та співвідношення між ними. Наукове розуміння процесу становлення людської особистості як саморуху визначається єдністю його зовнішніх і внутрішніх умов. Зовнішні умови - це умови природного та суспільного середовища, що потрібні для існування людини, їі життєдіяльності, навчання, освіти, праці, для реалізації можливостей розвитку. Погоджується Г.С. Костюк із думкою С.Л. Рубінштейна, що зовнішні умови завжди діють на цей процес через внутрішні умови, що є в самому індивіді, у суб'єкті. Від індивідуальних особливостей людини, їїпотребтаіншихсуб'єктивнихвластивостей залежить, що саме із зовнішнього, об'єктивного середовища є для неї значущим, впливає на неї та $€$ фактором її активності.

Зовнішні та внутрішні умови розвитку, стверджує Г.С. Костюк, є протилежностями, але вони не тільки взаємопов'язані, а й переходять одна в одну. «Зовнішнє, об'єктивне, засвоюючись індивідом, - пише Григорій Силович, - стає внутрішнім, суб'єктивним його надбанням, що визначає нове його ставлення до зовнішнього світу. Отже, відбувається «інтеріоризація» дій (практичних, розумових, мовних), формується здатність оперувати об'єктами в образах, думках, перетворювати їх подумки та водночас виявляти ці процеси назовні («екстеріоризувати» ї)» [3, с. 90]. Таким чином, продовжуючи вищезазначені думки, Г.С. Костюк зауважує, що зовнішне стає внутрішнім, зазнаючи змін, перетворень. Складним визнається і процес об'єктивації внутрішнього.

Співзвучною є думкаГ.С. Костюка з думками українських представників київської школи філософської психології кінця XIX - поч. XX ст. щодо зміни в ході розвитку людини співвідношення зовнішнього та внутрішнього, яке набуває своїх особливостей на різних етапах цього процесу. Внутрішні умови не залишаються одними й тими самими на всіх його ступенях, вони невпинно збагачуються через діяльність людини. Завдяки цьому уможливлюється ії нове ставлення до зовнішнього світу, яке пов'язане з новими цілями, потребами, інтересами, смислами. Те, до чого вона була байдужа, набуває для неї значущості та привабливості.

Г.С. Костюк внутрішні суперечності визначає як рушійні сили психічного розвитку людини. Внутрішні суперечності, що виникають у житті людини, спонукають її до активності, спрямованої на їх подолання. Однією з основних суперечностей, що закономірно виявляється на всіх вікових ступенях, є розходження між новими потребами, цілями, прагненнями особистості, яка розвивається, і досягнутим нею рівнем оволодіння засобами, необхідними для їх задоволення. Мотиваційна сторона розвитку особистості випереджає його операційну та змістову сторони.

Суперечності виникають також між досягнутим рівнем розвитку людини і способом іiї життя, місцем, яке вона посідає в системі суспільних відносин. Розвиток особистості виявляється і у разі встановлення окремих сторін її психічного життя: перехід від перцептивного до мисленнєвого пізнання дитиною предметів і явищ об'єктивної дійсності, від нижчих до вищих ступенів розвитку мислення й мовлення, від аналітичного відокремлення різних ознак об'єктів до синтетичного їх відображення. Внутрішні суперечності мають місце у становленні нових потреб та інших мотивів діяльності особистості. Її становлення не обходиться, зауважує Г.С. Костюк, без боротьби старого і нового, без вироблення здатності підпорядковувати ближчі, безпосередні мотиви, більш віддаленими, опосередкованими мотивами діяльності. Розвиток емоцій також характеризується своїми специфічними суперечностями. Емоції мають полярні якості, що переживаються як протилежності (задоволення - незадоволення, радість - сум, впевненість - боязкість). Єдність і боротьба цих протилежностей є важливою в розвитку емоцій, у переходах від ситуаційних емоційних станів до стійких почуттів, що є властивостями осо- 
бистості. У цьому процесі одні емоції усвідомлюються, зміцнюються та перетворюються на стійкі почуття через протилежні їм переживання. Суперечності властиві і для розвитку довільної регуляції поведінки підростаючої особистості, формування її самостійності, моральної волі.

Таким чином, зауважує Г.С. Костюк, на кожному етапі індивідуального розвитку особистості внутрішні суперечності набувають свого змісту, своїх форм виявлення та способів подолання, тобто вони розвиваються з розвитком її життєвих взаємин із навколишнім середовищем. «На перших порах суперечності не усвідомлюються суб'єктом, - пише Григорій Силович, - а на подальших етапах часто стають об'єктом його самосвідомості, переживаються ним як незадоволення собою, як свідоме, активне прагнення до самовдосконалення» [3, с. 93]. На психічний розвиток особистості діють соціальні чинники через ії діяльність, завдяки чому нею засвоюється соціальний досвід, забезпечується перехід зовнішніх, інтеріндивідуальних відносин у внутрішні, інтраіндивідуальні властивості особистості. Цей процес залежить від суб'єктних вимог, зокрема, від ставлення особистості до цієї діяльності, її внутрішньої позиції, сенсу для неї цієї діяльності. Через це однакові зовнішні обставини можуть впливати по-різному на розвиток особистості. Психічний розвиток особистості здійснюється в навчальній, ігровій, трудовій і професійній діяльності. Психічний розвиток особистості охоплює весь життєвий шлях людини, він здійснюється в ході безперервного навчання та виховання на власному досвіді й досвіді інших, діяльності.

Схожими видаються ідеї Йозефа Шванцари щодо психічного розвитку з ідеями, представленими в працях І.О. Сікорського («Начатки психологии», 1909; «Душа ребенка», 1911) і В.В. Зеньковського («Проблема психической причинности», 1914; «Психология детства», 1924). До таких ідей належить розуміння нормального розвитку людини, у якому спостерігаються зміни від менш досконалого до більш досконалого, і ці зміни відбуваються у визначеному часі, будучи відносно постійними, незворотними. Таким чином, розвиток визначається вченим як поступові, відносно незворотні зміни організму в часі. Але, спостерігаючи за розвитком людини, наприклад, емоційним розвитком, можна побачити, зазначає Йозеф Шванцара, що «тут справа стосується не якогось безперервного протікання, що в цьому ході життя можна спостерігати відомі інтервали, коли виникає дуже мало проявів, визначені інтервали, коли прояви, що розвинулись раніше, знаходять собі застосування, i, нарешті, періоди часу, коли з дитиною відбувається багато чого, коли ми можемо спостері- гати численні нові прояви або зміни поведінки, яка вже утворилась» [8, с. 15]. Спостерігаючи за дитиною від народження i, наприклад, до періоду юнацтва, можна її розвиток побачити як послідовність «кроків», котрі проходять через поточні цілі. Поступово диференціюється дифузне переживання єдності з матір'ю, дитина поступово підходить до усвідомлення самої себе. У людини відбувся не лише процес зростання, а також і процес розвитку, який являє собою якісні зміни. Йозеф Шванцара визначає розвиток як процес кількісних і якісних змін організму в часі. За переконаннями вченого процес розвитку відбувається в єдності організму та середовища, впливу культури й дійсності. Окремі складники психіки знаходяться у взаєминах, а це означає, що в ході психічного розвитку відбуваються диференціація та інтеграція процесів, властивостей і якостей у нове ціле. Тому психічний розвиток має ознаки інтеграції [8].

Історія психології, історія людської душі та людського духу змальовується В.А. Роменцем відповідно до структурної логіки становлення, розгортання й здійснення вчинку. Вона така ж неповторна, необоротна й одинична, як історія окремої людини. Це - рух учинкової активності від найперших примітивних до вищих - досконалих і достеменних її рівнів.

Саме поняття «вчинок», стверджує В.А. Роменець, «становить ту історичну ланку, той вузол у логічному розвитку науки, який вбирає в себе, концентрує і змістовно найбільш повно розкриває структуру людської психіки, поведінки, перекидає логічний місток до вивчення питань, що безпосередньо торкаються провідних проблем етики, філософії взагалі» [4, с. 104]. У психології, стверджує вчений, вчинком $є$ моральна дія, позбавлення старого й набуття нового, єдність об'єктивного і суб'єктивного, «стрибок» у духовному розвитку людини, процес, джерелом якого $€$ мотивація, а сутність полягає в перетворенні моральної ситуації. Рушійною силою вчинку виявляється сама людина, переживаючи при цьому свободу своєї волі, і саме звідси, переконаний Володимир Андрійович, індивідуалізований зміст учинку і наявність «інтуїтивної» частки, яка істотно впливає на його спрямованість. Адже людині, вважає вчений, важко й навіть неможливо передбачити всі обставини вчинкута вірогідні напрями його здійснення [4].

В.А. Роменець визначає вчинок як спосіб самодетермінації в людській поведінці на основі самопізнання та самостворення з формуванням смислу життя як психологічної проблеми. Вчинок виявляється в соціальній активності людини або у внутрішньому психічному плані, або в етичному, або в єдності його суб'єктивних та об'єктивних сторін. Вчинок дозріває, констатує вчений, психологічне 
переходить в етичне - дію, причому всупереч закріпленому в суспільних нормах стану речей. B.А. Роменець був переконаний, що людина, вдосконалюючись, переходить на інші рівні активності та духовного розвитку, а моральність вчинку полягає у творенні моральних цінностей моральними засобами. Щодо аморальних вчинків, то вони, переконаний вчений, $€$ свідченням духовної деградації.

Цілісність ієдність душі, зазначає В.А. Роменець, відтворюють її як мікрокосмос, протиставлений макрокосмосу, де мікрокосмос психологічно означає, що психіка міститься не тільки в тілі людини, не обмежується його контурами, а сягає в просторову й часову безкінечність, тому весь видимий людиною світ визначений нею. «Отже, - пише вчений, можна сказати, що великий світ (макрокосмос) розкривається через світ малий, що психічний світ відкриває позицію бачення великого світу та $є$ його самоспогляданням» [5, с. 82].

Уся психіка, констатує Володимир Андрійович, становить своєрідний спосіб самовідображення світу. Психічне постає образом буття, його зрізом, що уможливлює самопізнання світу через людину. Кожен психічний світ людини є частинкою великого всезагального феноменального світу, його ділянкою, а не єдиним ізольованим зрізом, як річ у собі. Психічне розглядається вченим і як культурний феномен. Стосунки між людьми та їхні соціальні стосунки, установки так або інакше уможливлюються через психічне, усвідомлюються та стають чинником дії, вчинку. «Більше того, -пише В.А. Роменець, - психічне саме створює біологічні й соціальні чинники, створює культуру, зокрема культуру знака, як висловився Л.С. Виготський. А вже цей знак зумовлює саму поведінку. Немає біологічних і соціальних чинників поведінки, позбавлених свого психологічного носія. Формула «біо-соціо» теоретично безплідна, абстрактна і не показує, як можна зрушити з місця живу істоту, не кажучи вже про можливість реалізації доцільного вчинку. Дійсним чинником поведінки $€$ культура як психологічний феномен або психіка як культурний феномен» [5, с. 595-596]. У психіці здійснюється автодетермінація. Тут постає найповніше розгорнена форма причинності, адже людина визнає свої дії, виходячи з усієї сукупності пізнавальних предметів та явищ. Таким чином, автодетермінація психіки уможливлює самоорганізацію та самоскеровування.

Розвиток психіки людини на початковому етапі уможливлюється, на думку О.М. Ткаченка, завдяки здатності до відображення. Психічне відображення носить активний характер і виявляється, по-перше, у відборі чуттєвих, біологічно значущих сигналів (рівень організму); по-друге, у раціональному пізнанні в процесі засвоєння (рівень індивіда), та по-третє, у процесі творення суспільно-історичного досвіду (рівень особистості). Згідно з переконаннями вченого принцип відображення охоплює та пояснює всі рівні психічного відображення, розкриває загальне та специфічне, що властиве кожному з них. Надалі свій розвиток психічне продовжує в процесі життєдіяльності та в умовах діяльності, де творяться нові суспільно значущі продукти і діяльність носить творчо перетворюючий характер.

О.М. Ткаченко стверджує, що для визначення рушійних сил розвитку та становлення психічної організації поведінки та діяльності людини на трьох рівнях (організму, індивіда та особистості) вкрай важливим і обґрунтованим видається системний розгляд принципу розвитку психіки людини і зазначає, що «кожному рівню притаманний свій тип розвитку: організм розвивається в процесі визрівання та формування психофізіологічних структур, індивід - у процесі діяльності присвоєння (засвоєння), особистість - у процесі перетворюючої діяльності. Щоб запобігти непорозумінню, зазначимо, що в реальному процесі становлення людської особистості типи розвитку представлено не окремо й однозначно послідовно, а «інтегрально», 3 послідовним домінуванням одного з них» [7, с. 48].

Розвиток психіки на основі дозрівання притаманний загальнобіологічному та біопсихічному рівням детермінації поведінки. Соціопсихічному рівню становлення індивіда, зауважує Олександр Миколайович, притаманний інший тип розвитку, який відбувається у процесі присвоєння суспільно-історичного досвіду шляхом цілеспрямованого формування психічних структур у процесі взаємодії з дорослими. Соціальність цього типу розвитку полягає в тому, що він здійснюється, по-перше, у разі співпраці дитини з дорослим; по-друге, шляхом засвоєння допоміжних засобів (знаків і найпростіших знарядь праці); по-третє, у колективі та через певний колектив (сімейний, дитячий, змішаний).

Ключовим у розвитку психічних якостей людини як особистості О.М. Ткаченко називає творчість як процес творення нових суспільно-цінних матеріальних речей або продукування знань і творення культурно-історичних цінностей. «Творчість у своїй основі, - пише О.М. Ткаченко, - виступає одночасно зі створенням самого себе. Адже щоб створити новий суспільно цінний продукт, необхідно одночасно «створити» і свої здібності. Це не два процеси, а один. Створюючи новий продукт, людина створює саму себе» [7, с. 49-50]. Отже, підсумовує вчений, розуміння творчості з наукових позицій уможливлюється лише як процес саморозвитку, самореалізації, самооб'єктивації особистості на основі засвоєння суспільно-історичного досвіду. 
Типи розвитку, зокрема шляхом визрівання, научіння, присвоєння, творення в реальному онтогенетичному процесі становлення людини як особистості, здійснюються не ізольовано і не пов'язано. Вони діалектично переплітаються, стверджує О.М. Ткаченко і допускає лише визнання відносного домінування одного з них на кожному етапі психічного розвитку. Вказані типи розвитку притаманні певним типам детермінації поведінки: розвиток шляхом визрівання та научіння властивий загальнобіологічній і біопсихічній детермінації (рівень організму); розвиток шляхом присвоєння і творення суспільно-історичного досвіду характерний для соціопсихічного рівня детермінації (індивідного й особистісного). Саме в цьому, переконаний вчений, виявляє себе взаємозв'язок принципів детермінізму, розвитку, відображення та єдності психіки та діяльності.

Ідею стадіального розвитку психіки підтримує і А.В. Брушлінський, зауважуючи, що в процесі психічного розвитку з'ясовується органічний взаємозв'язок з його продуктами, тобто з тими утвореннями, котрі виникають на попередніх стадіях процесу та стають необхідними внутрішніми умовами для виникнення наступних стадій [1].

О.В. Запорожець вважав головною умовою психічного розвитку виконання дитиною практичних дій: сприйняття є згорнутою, перцептивною дією, що уподібнюється основним якостям об'єкта; мислення спочатку виникає як практичне (тобто дійове) узагальнення тощо. Надалі відбувається згортання зовнішніх форм дії та її інтеріоризація у внутрішній, суб'єктивний план активності психіки людини [2].

Висновки. Отже, особливо важливо для розкриття закономірностей розвитку встановити потенціал людського розвитку та пере- думови його актуалізації, виявити шляхи вдосконалення людської природи, можливості збалансувати темпи соціальних змін і розвитку людини, не завдаючи шкоди людині й гуманізуючи соціальні процеси. У вирішенні цих проблем важливе місце посідає дослідження соціальної детермінації розвитку людини.

Наукове прогнозування перспектив розвитку людини та можливість наукового управління цим процесом передбачають виявлення перш за все системи соціальних умов і обставин, котрі підвищать активність людини, сприятимуть формуванню в неї потреби та здібності до саморозвитку.

\section{ЛІТЕРАТУРА:}

1. Брушлинский А.В. Субъект: мышление, учение, воображение. Москва : Изд-во «Институт практической психологии», 1996. 392 с.

2. Запорожец А.В. Избранные психологические труды: в 2 томах. Том 1. Психическое развитие ребенка. Москва : Педагогика, 1986. 318 с.

3. Костюк Г.С. Навчально-виховний процес і психічний розвиток особистості / під ред. Л.М. Проколієнко; Упор. В.В. Андрієвська, Г.О. Балл, О.Т. Губко, О.В. Проскура. Київ : Рад. Школа, 1989. 609 с.

4. Роменець В.А. Вчинок і проблема детермінізму у вітчизняній психології. Київ, 1965. С. 104-108.

5. Роменець В.А. Історія психології XIX-XX століття : навчальний посібник. Київ : «Вища школа», 1995. $616 \mathrm{c}$.

6. Рубинштейн С.Л. Основы общей психологии. Санкт-Петербург : Питер, 2015. 705 с. (Серия «Мастера психологии»).

7. Ткаченко О.М. Генетичний та фрункціональний зв'язок засобів комунікації та мислення. Філософрська думка. 1971. № 3.

8. Шванцара Й. Диагностика психического развития / пер. с чешск. Г.А. Овсянников. Прага: АВИЦЕНУМ, 1978. 388 c. 